\title{
УДК:351
}

DOI:https://doi.org/10.32689/2618-0065-2020-2(4)-52-62

Борисов Андрій Вікторович, начальник науково-інформаційного відділу, Український науково-дослідний інститут цивільного захисту, м. Київ, вул. Рибальська, 18, 01011, Україна тел.: + 38 (096) 509-36-02, e-mail.: niv1966@ukr.net, https//orcid.org/0000-0001-6858-0492

\section{ДИСКУРСНЕ ПОЛЕ ПРОБЛЕМАТИКИ ФОРМУВАННЯ МЕХАНІЗМІВ ДЕРЖАВНОГО РЕГУЛЮВАННЯ ПОЖЕЖНОЇ БЕЗПЕКИ}

\begin{abstract}
Анотація. У статті розглядається дискурсне поле проблематики формування механізмів державного регулювання пожежної безпеки. Вказується, що, за часів Середньовіччя, найбільші міста Європи постійно зазнавали лиха від руйнівних пожеж. Неодноразово спустошувалися вогнем Москва та Київ, а Страсбург вигоряв вісім разів у XIV столітті. Берлін повністю вигоряв двічі. У Лондоні, 02 вересня 1666 року сталася така грандіозна пожежа, яку неможливо було загасити впродовж п'яти днів. Руйнівна стихія знищила майже 13 тисяч будинків та 87 церков.

Зазначається, що під час середньовічних війн часто траплялися пожежі, але все ж таки основною причиною загоряння залишається людський фактор у поєднанні з примітивними будівельними технологіями, значною кількістю легкозаймистих матеріалів для будівництва і невмінням людини адекватно протистояти вогню.
\end{abstract}

Визначено, що, розуміючи згубність пожеж, державний апарат, спочатку, хаотично і безсистемно, береться за впровадження механізмів державного регулювання боротьби 3 пожежами та їхніми наслідками. Утворюються невеликі формування жителів міст за прикладом військових дружин. Вони об'єднуються 3 метою ведення боротьби з вогнем самотужки - черпаками та відрами доставляють воду до місць загоряння, гасять пожежі підручними засобами. Відзначено, що постійна нависаюча загроза загоряння $\mathrm{y}$ багатонаселених містах, а особливо в літню пору, вимагала від людей дотримання заходів обережності. Тоді ж 3'являються перші, затверджені державою, правила, якими визначається, що необхідно робити населенню 3 метою недопущення пожежі, мінімізування іiі наслідків та понесення відповідальності за необережне поводження з вогнем.

Проаналізувавши досвід держав стародавнього світу, визначено закономірність, що воєнні підрозділи, в силу високого степеню своєї організації, були основним інструментом для гасіння пожеж. Така практика 
мала місце не лише у Стародавніх Римі та Китаї, а й у Вавілоні, Сгипті, Ірані та ін. Таким чином, поступово в механізмах державного регулювання розвитку пожежної безпеки склалося два основні напрями: попередження виникнення пожеж і організація гасіння пожеж.

Ключові слова: механізми державного регулювання розвитку пожежної безпеки, проблеми запобігання пожежам, Стародавній Рим, необережне ставлення з вогнем, перші знаряддя боротьби з вогнем.

Borisov Andrii Viktorovych, Head of the Scientific and Information Department, Ukrainian Research Institute of Civil Protection. Kiev, st. Rybalskaya, 18 01011, Ukraine tel .: + 38 (096) 509-36-02, e-mail .: niv1966@ukr.net, , https//orcid.org/0000-0001-6858-0492

\section{Discourse field of formation of mechanisms of public regulation of fire safety}

Abstract. The article deals with the discourse field of problems of formation of mechanisms of state regulation of fire safety. It is stated that, during the Middle Ages, the largest cities in Europe were constantly affected by devastating fires. Moscow and Kiev were repeatedly devastated by fire, and Strasbourg burned down eight times in the fourteenth century. Berlin completely burned out twice. In London, on September 2, 1666, such a grand fire began, which could not be extinguished for five days. The devastating element destroyed nearly 13,000 homes and 87 churches.

It is noted that during the medieval wars there were frequent fires, but still the main cause of the fire is the human factor, combined with primitive building technologies, a large number of flammable materials for construction and the inability of man to adequately resist fire.

It has been determined that, understanding the fatalities of fires, the state apparatus, at first, chaotically and haphazardly, undertakes the introduction of mechanisms of state regulation of fighting fires and their consequences. Small towns are formed, following the example of military wives. They are united for the purpose of combating fire on their own - ladders and buckets deliver water to places of fire, extinguish fires by improvised means. It is noted that the constant looming threat of fire in crowded cities, and especially in the summer, required people to take precautionary measures. At the same time, the first state-approved rules emerge to determine what people should do to prevent a fire, minimize its effects, and bear responsibility for the careless handling of fire.

Analyzing the experience of the states of the ancient world, it is determined that the military units, because of the high degree of their organization, were the main tool for extinguishing fires. This practice has taken place not only in Ancient Rome and China, but also in Babylon, Egypt, Iran and others. Thus, in the mechanisms of 
state regulation of the development of fire safety, there are two main directions: prevention of fires and organization of fire fighting.

Keywords: mechanisms of public regulation of fire safety development, problems of fire prevention, ancient Rome, careless attitude to fire, first fire fighting tools.

Постановка проблеми. Уміння здобувати вогонь і управляти ним задля забезпечення життєдіяльності та безпеки людства можна вважати одним із найвагоміших досягнень на шляху його розвитку. Однак, за невмілого використання вогонь може стати руйнівною силою. Незважаючи на те, що аналіз історії формування пожежної безпеки вже здійснений як вітчизняними, так i зарубіжними науковцями, на сьогодні, відсутня комплексна систематизація теоретико-методологічних засад функціонування механізмів державного управління у сфері пожежної безпеки через компаративний аналіз проблематики їх становлення та реалізації.

Аналіз досліджень та публікацій. У загальному вигляді, питаннями історичного аналізу механізмів регулювання пожежної безпеки займалася ціла низка авторів: Андрієнко М. В. [11], Борис О. П. [1], Нєхаєв В.С. [6], Тітков, В. І. [12], Щербина Я. Я. [7] та ін.

Мета статті - здійснити огляд дискурсного поля проблематики формування механізмів державного регулювання пожежної безпеки.

Виклад основного матеріалу дослідження. 3 того часу, як людина почала будувати житло не 3 каменю, а 3 деревини, такі лиха як пожежі стали невід'ємною частиною життя.

Впродовж усього періоду своєї еволюції, найбільші міста світу періодично зазнавали нищівних пожеж. Деякі з них навіть вигорали по декілька разів. Наприклад, старовинний Константинополь за період I - XIII століть зазнав близько 5 грандіозних пожеж. Не зважаючи на це, міста знищувались і відбудовувались наново, беручи до уваги досвід ліквідації минулих катастроф.

Перша письмова згадка про пожежу була знайдена на кам'яній плиті часів існування Вавілонського царства. Цей напис описував гасіння пожежі у Месопотамському місті Німруд 2800 року до н.е., а вже перші державні акти, які регулювали проблеми запобігання пожежам з'явилися у Стародавньому Китаї під час правління династії Іжау, приблизно 1100 року до н.е. Також, до IV ст. до н.е. можна віднести задокументовані згадки про створення спеціальних команд для боротьби 3 пожежами у Японії та Стародавньому Китаї.

На території сучасної Європи перші згадки про професійну діяльність спеціальних пожежних підрозділів з'явилися у 6 році н.е. із прийняттям наказу імператора Октавіана Августа, який правив у Стародавньому Римі [1].

Пожежі завжди були одними 3 найтяжчих лих для народів усіх країн. Руйнівне полум'я обертало на попіл будинки, селища та, навіть, цілі міста. 
Влітку, 19 липня 64 року н.е., за часів володарювання імператора Нерона, в Римі сталася нестримна пожежа [2].

Десять 3 чотирнадцяти районів міста вигоріли вщент, зникло багато витворів мистецтва, храмів, житлових будинків, розплавилися три тисячі мідних дощок з постановами сенату з часів самого заснування Риму. За словами римського історика Корнелія Тацита, який у своїх роботах описував це страшне лихо, полум'я було нестримним, наступало, лютувало. Спочатку вогонь простягався на рівній місцевості, потім піднімався на височину і спрямовував знову вниз, чим не давав можливості боротися з ним. Внаслідок швидкості, 3 якою насувалася пожежа, і тому, що саме місто, з кривими вузькими вулицями і щільною забудовою, яким був стародавній Рим, легко стало його здобиччю.

Стаючи на захист римських сифонаріїв, які звинувачувалися у безсиллі при гасінні пожежі, німецький письменник-історик Ліндер відмічає, що «тільки надзвичайній енергії сифонаріїв, що розібрали цілі квартали, Рим зобов'язаний зупинці вогню». Пожежа змусила імператора Нерона замислитися над проблемами попередження пожеж і їх гасіння, бо в густонаселеному місті із вузькими вуличками, багатоповерховими, в чотири, п'ять і більше поверхів будинками, вогонь представляв серйозну небезпеку [3].

За часів Середньовіччя, найбільші міста Свропи, також, постійно зазнавали лиха від руйнівних пожеж. Неодноразово спустошувалися вогнем Москва та Київ, а Страсбург вигоряв вісім разів у XIV столітті. Берлін повністю вигоряв двічі. У Лондоні, 02 вересня 1666, року зайнялася така грандіозна пожежа, яку неможливо було загасити впродовж п'яти днів. Руйнівна стихія знищила майже 13 тисяч будинків та 87 церков.

Ця трагедія була настільки жахаючою та болючою, що в пам'ять про неї в Лондонському Сіті було зведено меморіал, будівництво якого тривало 6 років.

3 часом, люди навчилися використовувати вогонь не лише в побуті, а й як засіб оборони. Однією із найтрагічніших подій Вітчизняної війни 1812 року проти наполеонівських армій стала пожежа в Москві, де з 9151 будинків у місті 6596 вигоріли до тла [2].

Із зібраного матеріалу, можна зробити висновок, що під час середньовічних війн часто траплялися пожежі, але все ж таки основною причиною загоряння залишається людський фактор у поєднанні 3 примітивними будівельними технологіями, значною кількістю легкозаймистих матеріалів для будівництва і невмінням людини адекватно протистояти вогню.

Говорячи про грандіозні пожежі, можна оминути увагою нищівну пожежу в Амстердамі 1421 та 1452 років; Копенгаген був вигорілий вщент у 1728 та 1795; Новий Орлеан постраждав від пожеж в 1788 та 1794 роках; пожежі у Нью-Йорку 1776 та 1835 років; Москва горіла щонайменше чотири рази лише у період між 1547 та 1812 роками [4]. 
Як бачимо, навіть у найрозвинутіших країнах античності, середньовіччя та нового часу пожежами часто спустошувалися густонаселені міста, в яких гинуло населення та втрачалися надбані матеріальні цінності.

Розуміючи нищівну силу вогню, від невмілого поводження з ним, або від природних факторів, людство почало поступово запроваджувати механізми державного регулювання розвитку пожежної безпеки, маючи на меті попередження виникнення пожеж, ефективну боротьбу з вогнем та усунення наслідків.

Про появу перших державних заходів щодо боротьби 3 пожежами говорить В. Тітков. У своєму дослідженні він вказує на те, що покарання винних за необережне ставлення з вогнем були започатковані у Вавилоні та Ассирії. За його словами, ассирійське право відрізняється особливою жорстокістю покарань. У часи, коли правив цар Хаммурапі, а саме у 1800 році до н.е., була започаткована низка законів, один з яких дозволяв спалювати на вогнищі ту людину, яка під час пожежі крала знаряддя іï гасіння. Також, передбачалося, що сусіди мали допомагати одне одному при гасінні пожежі.

Надаючи опис цього закону у своїй роботі, В. Тітков робить висновок, що знаряддя боротьби з вогнем у Ассирії коштували дорого та були в обмеженій кількості. Погоджуюся з автором та хочу додати, що, можливо, покарання за крадіжку знарядь боротьби 3 вогнем було суворим, невчасно ліквідована пожежа могла потягти за собою низку загорянь інших споруд. Попри це, не можу повністю погодитися 3 автором стосовно його аналізу ассирійських законів у тій частині, де він припускає суспільне гасіння пожежі сусідами, тому що у наведеному законі такий обов'язок не зазначений і не є очевидним [5, с. 12].

В той же час, В. Нехаєв [6, с. 44] зазначає, що із розростанням поселень та міст збільшується й кількість «горючого» для пожеж. Він говорить про те, що чим більше розбудовувалися міста, тим трагічніше люди потерпали від вогню.

Розуміючи згубність пожеж, державний апарат, спочатку, хаотично і безсистемно, береться за впровадження механізмів державного регулювання боротьби 3 пожежами та їхніми наслідками. Утворюються невеликі формування жителів міст за прикладом військових дружин. Вони об'єднуються 3 метою ведення боротьби 3 вогнем самотужки - черпаками та відрами доставляють воду до місць загоряння, гасять пожежі підручними засобами.

Вони розбирають споруди на шляху вогню, щоб «відібрати» паливо у пожежі, надають порятунок маленьким дітям, безпомічним старим, рятують майно від знищення. Тоді, 3'являються перші засоби для гасіння вогню насоси.

Вважаю, що винахід насосу можна приймати за початок нової епохи у пожежній справі. Також, це могло вчинити суттєвий вплив на запровадження нових механізмів державного регулювання розвитку пожежної безпеки. Хоча, існують відомості про те, що у Стародавній Греції, ще за двісті років до н.е. 
уже був створений перший пожежний насос винахідником Ктесібієм, в той час як учень Ктесібія - Герон - винайшов поворотну трубу, завдяки чому насоси стали ще зручнішими до використання під час гасіння пожеж [7, с. 13].

Для боротьби 3 пожежами у Римській імперії було створено сім воєнізованих загонів. В озброєнні пожежних команд були такі інструменти як: сходи, відра, спеціальні просочені оцтом покривала. В обов'язки цих загонів входили: попередження та гасіння пожеж, забезпечуючи тим самим безпеку громадян. Римським правовим актом «Закони XII таблиць» було заборонено розводити похоронні вогнища поблизу будь-яких будівель. Також, у ньому зазначалося про те, що у кожного домовласника повинні бути: достатній запас води, ломів, сокир, лопат, сходів та вовняних ковдр для боротьби 3 вогнем [6, c. 29].

«Закони XII таблиць» прийнято вважати першим систематизованим збірником звичаїв населення Римської імперії, які мали статус обов'язкових правил, затверджених на рівні держави. Ці правила були прийняті ще за часів становлення держави близько 450 року до н.е. Проте, походження даної збірки залишається достовірно невідомим. Деякі науковці вважають, що «Закони XII таблиць» повністю відповідають рівню розвитку Римської Імперії того часу, тоді як інші схиляються до думки, що певні закони зі збірки були запозичені із грецької збірки законів Солона.

Та, незважаючи на ці обставини, «Закони XII таблиць» залишаються найважливішим джерелом, яке дає нам зрозуміти, коли почали зароджуватися перші механізми державного регулювання розвитку пожежної безпеки у Римі [8, с. 12].

Зважаючи на те, що Римська імперія була мало не найрозвинутішою державою стародавнього світу 3 точки зору державного устрою та розвитку державних механізмів, все ж варто звернути увагу на дослідження системи іiі пожежної безпеки.

Пожежі були справжньою «божою карою» для Стародавнього Риму. Через недостатність інформації про розвиток механізмів державного регулювання пожежної безпеки, у той час, ми вважаємо, що вони були недосконалими та примітивними. Проте, існують відомості, що у Римській імперії несла варту колегія «нічних тріумвірів». Їх основний обов'язок полягав у тому, щоб у нічний час вони стежили за порядком у місті та обходили його околиці. В їхні обов'язки, також, входило гасіння виникаючих пожеж [9, с. 34].

У 6 році н.е., у Римі відбулася страшна пожежа, під час якої полум'ям була охоплена більша частина міста. Імператор Октавіан Август прийняв рішення зібрати пожежний загін для ії ліквідації і розпустити його після того, як небезпека мине. Але він побачив, якою необхідною та незамінною є робота пожежників і вирішив не розпускати пожежний загін. Таким чином, у Римі 3'явився перший пожежний корпус, який нараховував 7000 людей. Він отримав назву «вігілі», або ті, які пильнують [10, с. 34]. 
На мою думку, можна говорити, що 3 цією подією розпочалося формування механізмів державного регулювання розвитку пожежної безпеки у Стародавньому світі.

В. Нехаєв у своїх роботах пише про те, що у період володарювання імператора Римської імперії Октавіана Августа (27 р. до н.е. - 14 р. н.е.) місто Рим налічувало чотирнадцять районів. Для боротьби 3 вогнем було започатковано сім воєнізованих когорт (загонів) нічної варти: по одній когорті на два райони. Когорту очолював трибун, якому підпорядковувалося двадцять дев'ять центуріонів - офіцерів нижчої ланки. Такі загони, в своїй більшості, комплектувалися вільновідпущениками, віком 17-47 років, які несли службу щоночі від Заходу і до Сходу сонця та перебували на казарменому положенні. Одна частина когорти, несла службу на постах вартових веж, розміщених у житловій частині міста, а інша - пішки або верхи на конях курсувала містом 3 дозорами [6, с. 45].

У контексті історико-державного аналізу, варто зазначити, що постійна нависаюча загроза загоряння у багатонаселених містах, а особливо в літню пору, вимагала від людей дотримання заходів обережності. Тоді ж з'являються перші, затверджені державою, правила, якими визначається, що необхідно робити населенню з метою недопущення пожежі, мінімізування їі наслідків та понесення відповідальності за необережне поводження з вогнем.

За словами М. Сергієнка, у Стародавньому Римі префект призначався самим імператором 3 числа вершників. Суду префекта підлягали крадії, грабіжники та підпалювачі. Він мав проводити розслідування кожного випадку пожежі і якщо пожежа виникла через необережність, префект накладав грошовий штраф на винуватого. У випадку, коли мало місце навмисного підпалу, винуватий міг бути засудженй до смертної кари [11].

В. Тітков стосовно започаткування механізмів державного регулювання розвитком пожежної безпеки говорить про те, що найперша згадка про існування спеціалізованих команд 3 гасіння пожеж зустрічається у Стародавньому Китаї та Японії. За результатами його дослідження, перші пожежні загони з'явилися у Китаї у IV столітті до н.е. Їх характерною особливістю була спеціальна форма та те, що під час їхнього виїзду на пожежу перед загоном обов’язково мав курсувати оркестр.

Китайськими законами при настанні темряви населенню заборонялося розводити вогнища з метою запобігання пожежам. Порушення цього правила каралося сотнею ударів батогом. У випадку, коли необережність мешканця спричиняла пожежу, йому , за цим законом, мали відсікати голову.

Під час правління китайської династії Хань, у ІІІ столітті до н.е., у державі почали з'являтися установи, які виконували завдання управління пожежною безпекою імператорського палацу та усього міста. Регулювання роботи цих установ покладалося на плечі чиновників, які слідкували за громадським порядком. Огляд міста здійснювався зі спеціальних оглядових веж. 
Найвагомішим досягненням у запровадженні пожежної безпеки жителями Стародавнього Китаю можна вважати переміщення місця для вогнища, де готували їжу та тримали запаси палива, у спеціальні окремі місця [12, с. 14].

Детально описує започаткування перших механізмів державного регулювання пожежною безпекою у Стародавньому Китаї Д. Грей [13, с. 14].

Для того, щоб уберегти міста від руйнівних пожеж, китайці дотримувалися ряду необхідних заходів. На вулицях багатьох міст були вириті колодязі, що носили назву тайпин-цзин, або колодязі Великого спокою. Вони були чималих розмірів і містили значні запаси води. Отвір такого колодязя був закладений кам'яною плитою, яку прибирали лише тоді, коли поблизу горів який-небудь будинок. Згідно із законом, у різних частинах китайського міста варто було тримати великі чани, постійно наповнені водою.

У кожному великому місті було декілька пожежних команд, які утримувалися повністю за рахунок пожертвувань городян. Пожежні насоси, які їм належали, відра з водою і ліхтарі, як правило, зберігалися в різних міських храмах. Кожна пожежна команда мала свою назву і була прикріплена до гільдії, або цеху, і витрати на іiі утримання оплачувалися членами цеху; солдати й офіцери були забезпечені спеціальною уніформою і на їхніх шапках великими ієрогліфами були написані назва, або номер, команди, а, також, слова «Цзюхо», що означало «гаситель вогню».

Вище нами вже були названі заходи обережності, які здійснювалидля гасіння пожеж самі городяни. Місцевий міський уряд, також, повинен був їм сприяти. Д. Греєм було взято за приклад місто Кантон. Кожен магістрат цього міста мав у підпорядкуванні декілька чоловік, у чиї обов'язки входило запобігання грабежам при пожежах. Так, гуансе, або начальникові китайського гарнізону в Кантоні, було підпорядковано вісімдесяти чоловік, окрім інших, двадцять з яких повинні були брати участь у ліквідації грабежів при пожежах, а шістдесят безпосередньо гасити вогонь. Сорок пожежників 3 цих вісімдесяти були розташовані біля міських воріт П'яти Геніїв, а інші сорок - у західному передмісті.

У безпосередньому підпорядкуванні губернатору знаходилися двісті чоловік, чиї основні обов'язки полягали у допомозі пожежникам при виникненні особливо серйозних лих. В усьому Кантоні було розміщено сорок вісім караульних приміщень і 3 кожного 3 них при виникненні пожежі відряджалися до місця події по дві людини. У кінці, або на початку, кожного подальшого місяця впродовж року суддя і скарбник провінції, обоє чиновники дуже високого рангу, були зобов'язані інспектувати усіх урядових службовців, які брали участь у гасінні пожеж.

Через декілька днів після ліквідації серйозної пожежі члени кожної пожежної команди, які брали участь у гасінні вогню, отримували смажених поросят, глеки вина і невеликі суми грошей на знак вдячності за хорошу службу. Люди, на яких був покладений небезпечний обов'язок тримати 
брандспойти, в таких випадках, отримували додаткову премію від держави. Пораненим пожежникам надавалася компенсація, розмір якої залежав від того, яке поранення вони отримували.

Проаналізувавши дослідження Д. Грея можна прийти до висновку, що в стародавні часи в Китаї вже існували певні механізми державного регулювання пожежною безпекою, які були досить розвинуті для свого часу.

Висновки. Проаналізувавши досвід держав стародавнього світу, визначено таку закономірність, що воєнні підрозділи, в силу високого степеню своєї організації, були основним інструментом для гасіння пожеж. Така практика мала місце не лише у Стародавніх Римі та Китаї, а й у Вавілоні, Єгипті, Ірані та ін. Таким чином, поступово в механізмах державного регулювання розвитку пожежної безпеки склалося два основні напрями: попередження виникнення пожеж і організація гасіння пожеж.

Тобто, підсумовуючи матеріали дослідження та беручи за приклад розвиток механізмів державного регулювання пожеж в найрозвинутішій державі того часу Стародавньому Римі, можна зробити висновок про зародження перших механізмів державного регулювання пожежної безпеки у стародавньому світі (див. Рис. 1.).

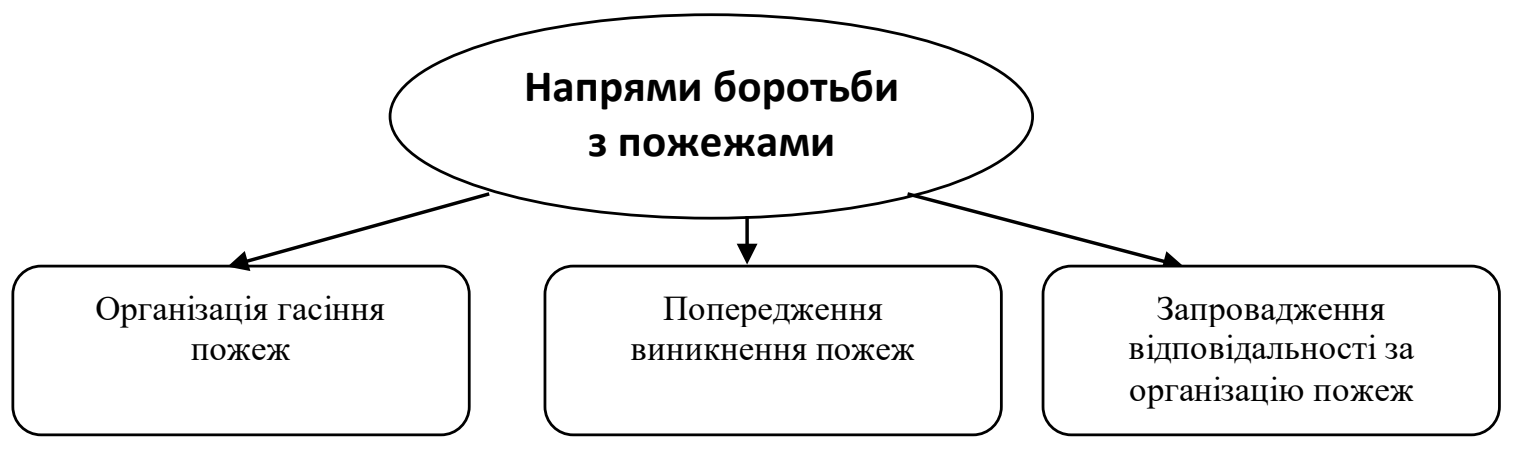

Рис. 1.Напрями боротьби з пожежами на державному рівні

\section{Jimepamypa:}

1. Борис О. П. Історія становлення державної пожежної охорони та ії роль у формуванні системи цивільного захсту України / О. П. Борис. // Державне управління: удосконалення та розвиток. - 2017. - № $1 . \quad$ - Режим доступу: http://www.dy.nayka.com.ua/?op=1\&z=1330

2. http://www.sgau.ru/files/pages/26155/14714301410.pdf

3. Офіційна сторінка «ДСНС України» на фейсбук / публікація від 11.12.2014 року Електронний ресурс - Режим доступу: https://www.facebook.com/MNS.GOV.UA/?hc_ref=ARSCEfgAL9yT5Coy_IfuX_hGAXcuvC 8jnCAJHJD1n1OX_Ypux7z5hyYsJMGdQAla50o\&fref=nf\&_tn_=kC-R

4. Охорона праці і пожежна безпека / електронний журнал / Новини 04.07.2016 року http://oppb.com.ua/news/nayvidomishi-pozhezhi

5. Титков, В. И. Четвертая стихия. Из истории борьбы с огнем Текст. / В. И. Титков. М : Объединенная редакция МВД России, 1998 г., 192 с. - с. 12 
6. Нєхаєв В.С. Вогнеборці Запоріжжя / В.С. Нєхаєв, М.А. Серцов. Запоріжжя: Видавничо-поліграфічний комплекс «Запоріжжя», 1997. 316 с - с. 44

7. Щербина Я. Я. Основы противопожарной техники / Я. Я. Щербина. - К.: «Вища школа», 1970. - 212 с. С. 13

8. История государства и права зарубежных стран [Текст] : учебник для студ. юрид. вузов и фак. - М. : НОРМА, 1996 .Ч. 1 / О. А. Жидков [и др.] ; общ. ред. Н. А. Крашенинникова, О. А. Жидков. - [Б. м.] : [б.в.], 1996. - 480 с. - с. 12

9. Сергеенко М.Е. Жизнь древнего Рима. СПб.: Издательско-торговый дом «Летний Сад», 2000. 368 с. - с. 34

10. Сергеенко М.Е. Простые люди древней Италии. М., 1964. 153 с. - с. 34

11. Андрієнко М. В. Історичні підгрунтя щодо виникнення державного управління сферою пожежної безпеки / М. В. Андрієнко. // Державне управління: удосконалення та розвиток. - 2014. - № 4. - Режим доступу: http://nbuv.gov.ua/UJRN/Duur_2014_4_11.

12. Титков, В. И. Четвертая стихия. Из истории борьбы с огнем Текст. / В. И. Титков. М : Объединенная редакция МВД России, 1998 г., 192 с.- с. 14

13. Д. Грэй История Древнего Китая / Издательство «Центрполиграф» / 2006 г 1224 c - c 14 http://loveread.ec/read_book.php?id=74261\&p=4

\section{References:}

1. Borys, O.P. (2017). Istoriia stanovlennia derzhavnoi pozhezhnoi okhorony ta yii rol u formuvanni systemy tsyvilnoho zakhstu Ukrainy [History of the formation of the state fire protection and its role in the formation of the system of civil protection of Ukraine]. Derzhavne upravlinnia: udoskonalennia ta rozvytok - Public administration: improvement and development, 1. Retrieved from http://www.dy.nayka.com.ua/?op=1\&z=1330 [in Ukrainian].

2. Khizov, A.V. (2016). Istoriya pozharnoy okhrany [The history of fire protection]. Saratov: FGBOU VO «Saratovskiy GAU». Retrieved from http://www.sgau.ru/files/pages/26155/14714301410.pdf [in Russian].

3. Ofitsiina storinka «DSNS Ukrainy» na feisbuk [Official page of the State Emergency Service of Ukraine on Facebook]. www.facebook.com. Retrieved from https://www.facebook.com/MNS.GOV.UA/?hc_ref=ARSCEfgAL9yT5Coy_IfuX_hGAXcuvC8j nCAJHJD1n1OX_Ypux7z5hyYsJMGdQAla50o\&fref=nf\&_tn_=kC-R [in Ukrainian].

4. Naividomishi pozhezhi [The most famous fires]. (2016). oppb.com.ua. Retrieved from http://oppb.com.ua/news/nayvidomishi-pozhezhi [in Ukrainian].

5. Titkov, V.I. (1998). Chetvertaya stikhiya. Iz istorii borby s ognem [The Fourth Element. From the story of the fight against fire]. Moscow: Obedinennaya redaktsiya MVD Rossii [in Russian].

6. Niekhaiev, V.S., Sertsov, M.A. (1997). Vohnebortsi Zaporizhzhia [Zaporozhye Fire Fighters]. Zaporizhzhia: Vydavnycho-polihrafichnyi kompleks «Zaporizhzhia» [in Ukrainian].

7. Shcherbina, Ya.Ya. (1970). Osnovy protivopozharnoy tekhniki [Fundamentals of firefighting equipment]. Kyiv: «Vyshcha shkola» [in Russian].

8. Zhidkov, O.A., et al. (1996). Istoriya gosudarstva i prava zarubezhnykh stran [History of the state and law of foreign countries]. (Vol. 1). N. A. Krasheninnikova, O. A. Zhidkov (Eds.). Moscow: NORMA [in Russian].

9. Sergeenko, M.E. (2000). Zhizn drevnego Rima [The life of ancient Rome]. Saint Petersburg: Izdatelsko-torgovyy dom «Letniy Sad» [in Russian].

10. Sergeenko, M.E. (1964). Prostye lyudi drevney Italii [Ordinary people of ancient Italy]. Moscow [in Russian]. 
11. Andriienko, M.V. (2014). Istorychni pidgruntia shchodo vynyknennia derzhavnoho upravlinnia sferoiu pozhezhnoi bezpeky [Historical education of the reign of the sovereign governing the sphere of fire-safe bezpeka]. Derzhavne upravlinnia: udoskonalennia ta rozvytokState control: comfortable and convenient development, 4. Retrieved from http://nbuv.gov.ua/UJRN/Duur_2014_4_11 [in Ukrainian].

12. Titkov, V.I. (1998). Chetvertaya stikhiya. Iz istorii borby s ognem [The Fourth Element. From the story of the fight against fire]. Moscow: Obedinennaya redaktsiya MVD Rossii [in Russian].

13. Gray, D. (2006). Istoriya Drevnego Kitaya [China: A History of the Laws, Manners and Customs of the People (Dover Books on Literature and Drama)]. Izdatel'stvo «Tsentrpoligraf». Retrieved from http://loveread.ec/read_book.php?id=74261\&p=4 [in Russian]. 